\title{
Endogenous changes exhibited by Le-Conte pear trees subjected to various irrigation regimes and their impact on vegetative growth
}

\author{
Stino*, R.G.; M.A Abd El-Mohsen*; M. E. Shawky**; M. M, Yhia***; M. A, \\ Abd-El-Wahab*** \\ * Pomology, Fac. Agric., Cairo University \\ ** Soil, Water and Enviro. Fac. Agric., Cairo University \\ *** Horticultural Research Inst. Agric. Res. Cent. Giza, Egypt. \\ Corresponding author: Mohamedabdelwab50@yahoo.com
}

\begin{abstract}
This study was carried out during three successive seasons 2013, 2014 and 2015 on seventeen years old LeConte pear trees. The first season was a preliminary season to eliminate the residual effects of the previously used irrigation treatments. Pear growing season was into four phenological stages (stage I beginning of flowering to final fruit set, stage II from initial fruit set to final fruit set, stage III final fruit set to harvesting and stage IV harvesting to leaf shed). Control trees received $100 \%$ of crop water requirement during all stages while the remaining trees received either of three water regimes $(60,80$ or $120 \%$ of crop water requirement) applied at one of the specified phenological stages and then irrigated with $100 \%$ of the requirements for the remaining. The effects of applied regimes on some vegetative growth parameters, enzymatic activities activity, phytohormons, total proteins, carbohydrates, phenols and proline were assessed. Results showed clear enhancements in vegetative growth induced by applying $120 \%$ of the actual requirement during any of the considered stages, proline declined by increasing the applied water quantities, whereas, an opposite trend was evident with protein content. Lowest irrigation regime (60\%) added at any of the considered stages significantly induced highest leaf carbohydrates, phenol content, polyphenol oxidase (PPO) \& Peroxidase (Pro) activates, $\mathrm{ABA}$ and SA content when compared with higher irrigation regimes at same stages. Growth promoting hormones as $\mathrm{GA}_{3}$, IAA and CKs contents attained an opposite trend. Finally it was concluded that various responses of vegetative growth to applied regimes was a reflection of the endogenous changes exhibited by the trees.
\end{abstract}

Key words: Le Conte pear- water regimes - vegetative growth - enzyme activity - carbohydrate - proteins- . $\mathrm{ABA}$ - SA - $\mathrm{GA}_{3}-\mathrm{IAA}$ - CKs

\section{Introduction}

Pear is one of the most important fruits grown worldwide. It ranks the sixth concerning the cultivated area. "Le Conte" is the main pear cultivar in Egypt with an acreage of 9404 feddans producing58852 tons (Ministry of Agriculture, 2013).

Water is the most limiting factor for crop production, especially in areas where agriculture relies heavily on irrigation. The importance of water in living organisms results from its unique physical and chemical properties, which also determine its functions in plant physiology. (Pretorius and. Wand 2003). Several authors indicated the promotive effects of the high levels of water supply on growth parameters (Azza et al, 2007).

Agriculture involves between $70 \%$ and $80 \%$ of the total water usage world-wide (FAO, 2006). The most recent forecast for climate change suggests a significant increment in temperature and a major reduction in the annual precipitation during the $21^{\text {st }}$ century leading to a $17 \%$ decline in the water resources available for agriculture world-wide (García-Tejero et al., 2010). Therefore, the current problems of shortage of water resources available for agriculture make it imperative to look for alternative methods of water deficit for our irrigation systems.

One of the options proposed for a more efficient use of irrigation water is the application of regulated deficit irrigation (RDI) (Mitchell et al., 1984). RDI is an important water-saving technique developed by Chalmers et al. (1981), which is based on the restriction of water supplies during certain stages of crop development, when yield and fruit quality have low sensitivity to a reduction in water, providing normal irrigation during the rest of the season, especially during the «critical periods» or phonological stages with a higher sensitivity to water deficit (Chalmers et al., 1986)..RDI techniques have been successfully applied to many fruit trees such as peaches (Chalmers et al., 1981), pears (Mitchell et al., 1986), Asian pears (Behboudian et al., 1994) and grapefruits (Cohen and Goell, 1988).

On pear trees, researchers reported various effects of regulated water deficits on vegetative growth, enzyme activity, and phytohormons under different climatic conditions (Marsal et al., 2000). Some investigators found that RDI techniques used from the early stages of fruit growth up to the end of 
shoot growth affected vegetative growth by inhibiting shoot development, but it did not affect the final fruit size, number of fruit produced or yield of the subsequent season (Li et al., 1989). Girona et al. (2005) found that a single RDI regime reduced irrigation by $13-24 \%$, while combined regimes reduced it by $23-35 \%$.

The vegetative growth of pear trees is recognized as being the most sensitive process to RDI. Reductions in shoot elongation and trunk cross sectional area in response to water deficits lead to reductions in tree size and smaller canopies (PérezPastor et al., 2009).

The main cause of the biochemical limitation under water-stress conditions is the accumulation of active oxygen species (AOS) and free radicals (Chaves and Oliveira, 2004) that damage cell membranes and lead to the accumulation of lipid peroxides (Edreva, 2005). The toxicity of AOS is normally counteracted by efficient scavenging by both non-enzymatic and enzymatic antioxidants present in the plant cells. Enzymatic antioxidants in leaves include peroxidases (Pro; EC 1.11.1.7) are also effective antioxidants and play an important role in the regulation of cell wall expansion (Fry, 1995). Finally, polyphenol oxidase (PPO; EC 1.30.3.1) isoenzymes, which oxidize o-diphenolic substrates to o-quinones (Kuwabara and Katoh, 1999) are involved in the metabolism of phenols that are also important antioxidants (Rice-Evans et al., 1997). As shown by Sofo et al,. (2005) the ability of olive trees to up-regulate the enzymatic antioxidant system may be an important factor underlying the drought tolerance of this species. Whereas the activity of peroxidase was increased with increasing drought severity and PPO activity decreased.

Plants subjected to water deficit may synthesize and accumulate amino acids, proteins, sugars, methylated quaternary ammonium compounds and organic acids (Ingram and Bartels 1996). These physiological responses permit fruit trees to lower their osmotic potential facilitating water flow into their roots and leaves, thus, maintaining cell turgor (Dichio et al., 2005). These solutes, also sequester water molecules, protect cell membranes and protein complexes and allow the metabolic machinery to continue functioning (Chaves et al., 2003). Carbohydrates are the most common solutes accumulated in plant tissues under water deficit conditions (Rejsková et al., 2007, Ben Ahmed et al., 2009) found that proline accumulated in olives under water deficit conditions. Furthermore, a close relationship between net photosynthetic rate and proline content was recorded, pointing the important role of this osmolyte in the maintenance of photosynthetic activity. Under mild and moderate water stress, photosynthetic rate decreases in plants mostly due to stomatal closure (Angelopoulos et al., 1996) .However, as water stress becomes severe, the inactivation of photosynthetic activity could be ascribed not only to stomatal restrictions, but also to non-stomatal factors related to inhibition of primary photochemistry and electron transport in chloroplasts (Boyer et al., 1987). Frequently, under water stress the rate of light absorption exceeds the capacity for photosynthesis. This often results in a repression of photosynthesis in a phenomenon known as photoinhibition (Grace, 2005).

Water stress affects many metabolic pathways mineral uptake, membrane structure, etc. Therefore it is not surprising that hormone contents can be also changed by water stress. This is very important because plant hormones are considered as main signals in root-to-shoot communication and vice versa (Naqvi, 1995). In consequence, the change in hormonal balance might play the key role in the sequence of events induced by stress (Itai, 1999).

The scope of this investigation is to find out the effect of various water regimes at specified phonological stages on the vegetative growth of LeConte pears and to try to explain the attained findings via endogenous changes in the chemical constituents of the leaves.

\section{Material and methods}

\section{Experimental conditions and plant material}

The present experiment was performed during 2013, 2014 and 2015 in a 2.5 feddans plot at a private orchard, located in El-Khatatba district, Minufiya governorate. Four hundred and twenty uniform mature "Le-Conte " pear trees budded on Pyrus communis rootstock, spaced $5 \times 5 \mathrm{~m}$, vase trained and subjected to cultural practices recommended by the Ministry of agricultural, with an average height of $3.5 \mathrm{~m}$, and ground cover of about $85 \%$ were adopted. Trees were drip irrigated using two drip irrigation lines for each row.

Soil physical and chemical properties were determined in the laboratory of the Soil, Water and Environmental Res. Inst. according to the methods described by Jakson (1973) and the results are summarizing in Table (1). The experimental design of each irrigation treatment was 4 standard experimental plots distributed randomly in blocks. The standard plot was made up of 15 trees, organized in 4 adjacent rows. The 3 central trees of the middle row were devoted for measurements (each tree acting as a replicate, and the other 12 trees were guard trees.

\section{Irrigation treatments:}

The present research study was initiated in 2013and extended for three successive growing seasons. The first season was considered to be a preliminary season to eliminate the residual effects of the previously used irrigation treatments. Pear growing season was split to four phenological stages as presented in Table (2). 
Table 1. Physical and chemical properties of the orchard soil.

\begin{tabular}{|c|c|c|c|}
\hline & \multirow{3}{*}{ Parameter } & \multicolumn{2}{|c|}{ Soil sample depth } \\
\hline & & $0-30 \mathrm{~cm}$ & $30-60 \mathrm{~cm}$ \\
\hline & & \multicolumn{2}{|c|}{ Value } \\
\hline \multirow{5}{*}{$\begin{array}{l}\text { Physical } \\
\text { properties }\end{array}$} & Fine sand \% & 40.43 & 39.28 \\
\hline & Coarse sand \% & 45.18 & 48.00 \\
\hline & Silt \% & 5.66 & 3.35 \\
\hline & Clay \% & 8.73 & 9.37 \\
\hline & Texture class & Loam Sand & Loam Sand \\
\hline \multirow{11}{*}{$\begin{array}{l}\text { chemical } \\
\text { properties }\end{array}$} & $\mathrm{Ec}(\mathrm{ds} / \mathrm{m})$ & 9.25 & 3.98 \\
\hline & $\mathrm{Ca}++(\mathrm{me} / \mathrm{l})$ & 19.5 & 8.5 \\
\hline & $\mathrm{Mg}++$ & 53.5 & 25.5 \\
\hline & $\mathrm{Na}+$ & 16.4 & 3.5 \\
\hline & $\mathrm{K}+$ & 0.96 & 0.56 \\
\hline & Co3-- & - & - \\
\hline & $\mathrm{HCo} 3-$ & 5 & 4 \\
\hline & $\mathrm{Cl}-$ & 74.5 & 29 \\
\hline & So4-- & 10.86 & 5.06 \\
\hline & $\mathrm{PH}$ & 7.82 & 7.79 \\
\hline & $\mathrm{Sp} \%$ & 36.7 & 31.8 \\
\hline
\end{tabular}

Table 2. The adopted phonological stages

\begin{tabular}{llll}
\hline \multicolumn{1}{c}{ Phenological stage } & Date & $\begin{array}{l}\text { No. of days from beginning } \\
\text { of flowering }\end{array}$ \\
\hline stage & beginning 10\% flowering to final fruit set (six weeks & $07 / 03$ to & \\
I & after petal full) (F-I.FS) & $15 / 4 / 2014-15$ & 37 days \\
\hline stage & from initial fruit set (three weeks after petal full) to & $15 / 04$ to & \\
II & final fruit set (I.FS - F.FS) & $7 / 05 / 2014$ & 21 days \\
\hline stage & & $7 / 05$ to & \\
III & final fruit set to harvesting (F.FS- H) & $15 / 08 / 2014$ & 83 days \\
\hline stage & & $15 / 08$ to & \\
IV & harvesting to natural defoliation or leaf shed (H - D) & $1 / 11 / 2014$ & 75 days \\
\hline
\end{tabular}

However, control trees received $100 \%$ of irrigation requirement during all stages while the remaining trees received three water regimes $(60,80$ and $120 \%$ of irrigation requirement) applied at each of the phonological stages and then irrirgation was applied for the remaining stages with $100 \%$ of the water requirements. After the last phenological stage, irrigation was withheld till the commencement of stage I

The applied levels of irrigation were alculated as daily crop water requirements (liter/tree/day), as follow:

$1-$ The 1 st irrigation level (optimum rate) $=100 \%$ of the crop water requirement (CWR), this amount of water was calculated theoretically from the "TAHRIR" meteorological data of the planting region. 2 - The 2 nd irrigation level (high rate) $=120 \%$ of the CWR.

3 - The 3 rd irrigation level $($ moderate rate $)=80 \%$ of the CWR.

4 - The 4th irrigation level (low rate) $=60 \%$ of the CWR.
The relative requirements were applied by changing the number and or the discharge of emitters used. Water requirements for pear were calculated as elucidated by Karmeli and Keller (1975):

IR $=($ Se.SL.ETo.Kc.Kr/Ea)*(1/1-Lr)

IR $=$ Daily irrigation requirements

Se. = Plant area (Plant distance on lateral* betwee

SL laterals)

ETo = Daily reference evapotranspiration 0$]$ $\mathrm{mm} /$ day

$\mathrm{Kc}=$ Coefficient factor for pear trees (Allen, et al. 1998).

$\mathrm{Kr}=$ Reduction coefficient Gc/0.85

$\mathrm{Gc}=$ Ground cover (area of tree canopy)

$\mathrm{Ea}=$ Efficiency of irrigation system (80-90\%)

$\mathrm{Lr}=$ Leaching requirements $=\mathrm{Eci} / \mathrm{Ecd}$

Eci = Electrical conductivity of irrigation water

Ecd = Electrical conductivity of drainage water

Whereas, The ETo value was calculated using the atmospheric climatic conditions prevailing at ElKhatatba district. Crop irrigation requirements were 
scheduled weekly according to daily ETo, Since, Penman Monteith method was used to calculate ET crop for pear trees in the district during 2014 and 2015 seasons of study using CROPWAT model (Smith 1991).

$$
\begin{array}{ll}
\text { ETo }= & \frac{0.408 \Delta(\mathrm{Rn}-\mathrm{G})+\gamma[900 /(\mathrm{T}+273] \mathrm{U} 2 \text { (es-ea) }}{\Delta+\gamma(1+0.34 \mathrm{U} 2)} \\
\mathrm{ETo}= & \text { reference evapotranspiration, mm/day } \\
\mathrm{Rn}= & \text { net radiation }(\mathrm{MJm}-2 \mathrm{~d}-1) \\
\mathrm{G}= & \text { soil heat flux }(\mathrm{MJm}-2 \mathrm{~d}-1) \\
\Delta \quad= & \text { slope vapor pressure and temperature curv } \\
& \left(\mathrm{kPa}{ }^{\circ} \mathrm{C}-1\right) \\
\Gamma \quad= & \text { psychrometric constant }\left(\mathrm{kPa}{ }^{\circ} \mathrm{C}-1\right) \\
\mathrm{U} 2= & \text { wind speed at } 2 \mathrm{~m} \text { height }(\mathrm{ms}-1) \\
\text { es-ea }= & \text { vapor pressure deficit }(\mathrm{kPa}) \\
\mathrm{T}= & \text { daily air temperature at } 2 \mathrm{~m} \text { height }\left({ }^{\circ} \mathrm{C}\right)
\end{array}
$$

Crop coefficient (KC) value was used for quantifying crop water use. It was calculated from the equation: $\mathrm{KC}=\mathrm{ETc} / \mathrm{ETo}$; where ETc is ETe/ETo the actual water consumptive use and ETo is the reference (potential evapotranspiration).

The correction coefficient for ground cover was used according to Fereres and Goldhmaer (1990).

To unify the applied nutrients, application was done manually on weekly basis

\section{Assessments \\ Vegetative growth parameters}

A random sample of ten current year's shoots were tagged at the end of October for each tree devoted for morphological determinations. Average shoot length, shoot diameter, and number of leaves/shoot were measured.

Chemical analysis

At the end of each considered stage a sample of leaves from each replicate was collected for leaf chemical content determination. Total soluble carbohydrates content was determined using Anthrone technique according to (Umbriet et al., 1964). While, total water-soluble proteins content was determined according to the method of (Lowery et al., 1951) using casein as a standard protein. The colorimetric method of Folin-Denis as described by Daniel and George (1972) was employed for the chemical determination of phenolic compounds (mg/100 $\mathrm{g}$ of fresh $\mathrm{wt}$ ) as follows:

Total phenols $(\mathrm{mg} / 100 \mathrm{~g})=$

(X) ppmx Extract volume x 100

Sample dry weight $\mathrm{x} 1000 \times 1000$

$$
\mathrm{x}=\frac{\mathrm{y}-0.01072}{0.00904}
$$

Free proline content $(\mathrm{mg} / \mathrm{g} \mathrm{d} . \mathrm{wt})$ were determined according to the method described by Bates et al., (1973) as follows:

$\mathrm{Mg} / \mathrm{g}$ proline =

(X) ppmx ml Extract volume

2 x Sample dry weight $x 100$

The terminal buds in addition to the first and second young leaves were also used for the estimation of peroxidase (POX), polyphenol oxidase (PPO) enzymes contents. Two gm of the plant materials were homogenized with $10 \mathrm{ml}$ of phosphate buffer pH $6.8(0.1 \mathrm{M})$, then centrifuged at $2^{\circ} \mathrm{C}$ for 20 $\mathrm{min}$ at $20000 \mathrm{rpm}$ in a refrigerated centrifuge. The clear supernatant (containing the enzymes) was taken as the enzymes source (Mukherjee and Choudhuri 1983). One unit of enzyme activity was defined as the amount of the enzyme that resulted in $50 \%$ inhibition of the auto-oxidation rate of pyrogallol at $25{ }^{\circ} \mathrm{C}$ (Kong et al., 1999). Peroxidase activity was assayed according to the method of Bergmeyer, (1974). Poly phenol oxidase activity was assayed according to the method of Kar and Mishra, (1976).

During 2014 season at the end of each stage, samples of terminal buds were collected 72 hour to determine the endogenous hormones (IAA, $\mathrm{GA}_{3}$, cytokinin, $\mathrm{ABA}$, and $\mathrm{SA}$ ) in the terminal buds of the treated plants, as well as the control according to Knegt and Brunima (1973).

$\mathrm{C}_{18}$ sep-pak cartridge reversed phase was used to separate endogenous plant hormones (IAA, GA 3 , cytokinin, ABA and SA). This method was followed as described by (Lee et al., 1989). Then, these hormones were estimated by HPLC as follows:

Water U6K HOLC.

Column : Bondapak $\mathrm{C}_{18}$.

Dimension $\quad: 3.9 \times 300 \mathrm{~mm}$.

Mobil phase $\quad: \mathrm{MeOH}$ super purity $-2 \%$ acetic

acid.

Flow rate $\quad: 1.0 / \mathrm{min}$

Detection : UV waters $486-254 \mathrm{~nm}$.

Experimental design and statistical analysis: Split plot design was adopted for the experiments. The statistical analysis of the present data was carried out according to Snedecor and Chocran (1980). Averages were compared using MSTAT program. Least Significant Difference (LSD) was used to compare between means of treatments according to Duncan (1955) at probability of $0.5 \%$.

\section{Results}

Vegetative growth assessments: Applying $120 \%$ of the actual irrigation requirements during the first "phonological stage was the most effective regime in inducing statistically longest shoots in both seasons. On contrary in both seasons, significantly the shortest shoots were dedicated to applying $60 \%$ of the actual irrigation requirements during the second 
stage in the first season and I, III or IV stage in the second season (Table, 4 ).

With respect to the average shoot diameter, data in Table (4) cleared that highest irrigation regime $(120 \%)$ applied at second or first stage in first and second seasons respectively induced significantly the widest shoot diameter. On the other hand, the narrowest shoot diameter was due to applying $60 \%$ during stage 4 in the first season and III or IV in the second one.

Table 4. Effect of water regime on shoot length and shoot diameter.

\begin{tabular}{llllll}
\hline & & \multicolumn{2}{c}{ Shoot length (cm) } & \multicolumn{2}{c}{ shoot diameter(cm) } \\
\hline $\begin{array}{l}\text { \% of actual } \\
\text { requirements }\end{array}$ & phenological stages & 2014 & 2015 & 2014 & 2015 \\
\hline Control 100\% & all stages & 32.35 & 34.42 & 0.56 & 0.63 \\
\hline \multirow{2}{*}{$120 \%$} & stage I (F-I.FS) & 35.88 & 57.67 & 0.62 & 0.83 \\
& stage II (I.FS - F.FS) & 34.83 & 45.56 & 0.63 & 0.75 \\
& stage III (F.FS- H) & 33.00 & 40.00 & 0.58 & 0.74 \\
& stage IV (H - D) & 33.58 & 46.75 & 0.57 & 0.78 \\
\hline $80 \%$ & stage I (F-I.FS ) & 30.80 & 26.83 & 0.51 & 0.58 \\
& stage II (I.FS - F.FS) & 25.55 & 32.22 & 0.49 & 0.60 \\
& stage III (F.FS- H) & 24.42 & 33.00 & 0.51 & 0.59 \\
$60 \%$ & stage IV (H - D) & 28.19 & 31.68 & 0.52 & 0.52 \\
\hline LSD at 0.05 & stage I (F-I.FS ) & 23.58 & 25.56 & 0.45 & 0.51 \\
& stage II (I.FS - F.FS) & 20.42 & 26.56 & 0.43 & 0.55 \\
& stage III (F.FS- H) & 21.38 & 25.36 & 0.45 & 0.50 \\
& stage IV (H - D) & 22.76 & 25.75 & 0.40 & 0.49 \\
\hline
\end{tabular}

The average number of leaves per shoot was significantly the highest when applying $120 \%$ of the actual requirements in both seasons during stage I, II or III in the first season and only during stage III in the second. The effect of the afore mentioned regime when applied during stages I or II ranked the second in this respect with insignificant differences between application during both of them On the contrary, significantly the least number of leaves was attained by applied $60 \%$ of the actual irrigation requirements during stage IV in both seasons (table, 5).

As for the average leaf area, it is evident from table, (5) that the highest irrigation regime during stage I in the first season and IV in the second one induced statistically the largest leaves. Whereas significantly the smallest leaves were attributed to the lowest regime when applied during stage III and IV for both seasons respectively

Table 5. Effect of water regime on number of leaves and leaf area.

\begin{tabular}{|c|c|c|c|c|c|}
\hline \multirow{2}{*}{$\begin{array}{l}\% \text { of actual } \\
\text { requirements }\end{array}$} & \multirow[b]{2}{*}{ phenological stages } & \multicolumn{2}{|c|}{ number of leaves/shoot } & \multicolumn{2}{|c|}{ leaf area $(\mathrm{cm} 2)$} \\
\hline & & 2014 & 2015 & 2014 & 2015 \\
\hline Control $100 \%$ & during all stages & 13.72 & 16.78 & 26.55 & 30.30 \\
\hline \multirow{4}{*}{$120 \%$} & stage I (F-I.FS) & 17.11 & 23.33 & 33.54 & 35.33 \\
\hline & stage II (I.FS - F.FS) & 17.54 & 23.44 & 27.50 & 33.90 \\
\hline & stage III (F.FS- H) & 17.54 & 25.44 & 27.67 & 35.33 \\
\hline & stage IV (H - D) & 14.91 & 21.73 & 27.11 & 39.90 \\
\hline \multirow{4}{*}{$80 \%$} & stage I (F-I.FS ) & 12.90 & 16.00 & 23.80 & 27.00 \\
\hline & stage II (I.FS - F.FS) & 13.67 & 16.12 & 22.73 & 29.91 \\
\hline & stage III (F.FS- H) & 13.67 & 15.28 & 23.52 & 26.54 \\
\hline & stage IV (H - D) & 12.50 & 15.57 & 22.42 & 28.50 \\
\hline \multirow{4}{*}{$60 \%$} & stage I (F-I.FS ) & 12.10 & 15.14 & 21.35 & 26.23 \\
\hline & stage II (I.FS - F.FS) & 12.90 & 15.08 & 20.95 & 29.33 \\
\hline & stage III (F.FS- H) & 12.90 & 14.59 & 19.46 & 25.33 \\
\hline & stage IV (H - D) & 12.00 & 14.10 & 21.50 & 24.23 \\
\hline LSD at 0.05 & & 0.57 & 0.79 & 0.57 & 0.80 \\
\hline
\end{tabular}

As a general trend clear enhancements in the previously assessed parameters were induced by applying $120 \%$ of the actual requirement. Whereas, clear growth restriction was observed with the lowest regime applied.

\section{Changes in leaf constituents}

Significantly the highest proline content was attributed to applying the lowest irrigation regime during stage III. This content declined by increasing the applied water quantities to reach its' lower most 
level when applying $120 \%$ of the actual requirements during any of stages I, II or III with insignificant differences (table 6).

Statistically the highest leaf protein content was due to applying the highest regime during the first stage in both seasons. Reducing the applied water quantities to $60 \%$ of the actual requirements during stages I \&IV for both seasons respectively induced significantly the lowest protein content (table 6)

As a general observation proline content was increased with decreasing the applied water regime and vice versa. Whereas, an opposite trend was evident with protein content.

Table 6. Effect of water regime on leaf proline and protein

\begin{tabular}{llllll}
\hline & & \multicolumn{2}{c}{ Proline (mg/100g d.wt) } & \multicolumn{2}{c}{ Protein (mg/100g d.wt) } \\
\hline $\begin{array}{l}\text { \% of actual } \\
\text { requirements }\end{array}$ & phenological stages & 2014 & 2015 & 2014 & 2015 \\
\hline Control 100\% & during all stages & 0.86 & 0.88 & 3.82 & 3.91 \\
\hline \multirow{2}{*}{$120 \%$} & stage I (F-I.FS) & 0.71 & 0.77 & 5.61 & 5.21 \\
& stage II (I.FS - F.FS) & 0.78 & 0.73 & 4.91 & 4.30 \\
& stage III (F.FS- H) & 0.71 & 0.79 & 5.30 & 5.12 \\
& stage IV (H - D) & 0.18 & 0.15 & 4.21 & 4.12 \\
\hline $80 \%$ & stage I (F-I.FS ) & 1.78 & 1.89 & 3.31 & 3.21 \\
& stage II (I.FS - F.FS) & 1.88 & 1.90 & 3.45 & 3.12 \\
& stage III (F.FS- H) & 2.24 & 2.21 & 3.61 & 3.25 \\
$60 \%$ & stage IV (H - D) & 1.36 & 1.26 & 3.54 & 3.80 \\
\hline & stage I (F-I.FS ) & 1.98 & 1.97 & 2.54 & 2.15 \\
& stage II (I.FS - F.FS) & 2.10 & 2.15 & 2.90 & 2.70 \\
\hline LSD at 0.05 & stage III (F.FS- H) & 2.41 & 2.51 & 2.81 & 2.54 \\
& stage IV (H - D) & 1.59 & 1.70 & 2.15 & 2.95 \\
\hline
\end{tabular}

Data in Table (7) clear that lowest irrigation regime $(60 \%)$ added at different stages significantly induced highest leaf carbohydrates and phenol content when compared with higher irrigation regimes at same stages. However these parameters were decreased by increasing the amount of water applied for the same stage to reach it utmost with the $120 \%$ application at same.

Table 7. Effect of water regime on leaf carbohydrates and total phenols

\begin{tabular}{|c|c|c|c|c|c|}
\hline \multirow[b]{2}{*}{$\begin{array}{l}\% \text { of actual } \\
\text { requirements }\end{array}$} & \multirow[b]{2}{*}{ phenological stages } & \multicolumn{2}{|c|}{ carbohydrates $\mathrm{mg} / 100 \mathrm{~g} \mathrm{~d} . \mathrm{wt}$} & \multicolumn{2}{|c|}{ phenol (mg/100g d.wt) } \\
\hline & & 2014 & 2015 & 2014 & 2015 \\
\hline Control $100 \%$ & during all stages & 10.60 & 10.30 & 1.87 & 1.74 \\
\hline \multirow{4}{*}{$120 \%$} & stage I (F-I.FS) & 9.30 & 9.20 & 0.86 & 0.79 \\
\hline & stage II (I.FS - F.FS) & 7.63 & 7.25 & 0.93 & 0.81 \\
\hline & stage III (F.FS- H) & 9.35 & 9.21 & 1.60 & 1.10 \\
\hline & stage IV $(\mathrm{H}-\mathrm{D})$ & 8.45 & 8.21 & 0.95 & 0.89 \\
\hline \multirow{4}{*}{$80 \%$} & stage I (F-I.FS ) & 12.30 & 12.20 & 2.86 & 2.65 \\
\hline & stage II (I.FS - F.FS) & 11.50 & 11.30 & 2.58 & 2.47 \\
\hline & stage III (F.FS- H) & 10.90 & 10.50 & 3.23 & 3.89 \\
\hline & stage IV $(\mathrm{H}-\mathrm{D})$ & 10.60 & 10.30 & 2.55 & 1.53 \\
\hline \multirow{4}{*}{$60 \%$} & stage I (F-I.FS ) & 13.90 & 13.80 & 3.42 & 3.15 \\
\hline & stage II (I.FS - F.FS) & 12.90 & 12.70 & 4.50 & 4.10 \\
\hline & stage III (F.FS- H) & 12.60 & 12.10 & 3.46 & 3.23 \\
\hline & stage IV $(\mathrm{H}-\mathrm{D})$ & 11.90 & 11.30 & 3.96 & 3.76 \\
\hline LSD at 0.05 & & 0.29 & 0.19 & 0.2 & 0.10 \\
\hline
\end{tabular}

\section{Enzymatic activities}

The obtained results in Table (8) clear that the lowest irrigation regime $(60 \%)$ when applied during stage III induced the highest polyphenol oxidase
(PPO) and Peroxidase (Pro) activates. The afore mentioned activities decreased with increasing the applied water quantities for the same phenological stage. 
Table 8. Effect of water regime on polyphenol oxidase (PPO) and Peroxidase (Pro) activity

\begin{tabular}{lllccc}
\hline & & \multicolumn{2}{c}{ PPO } & \multicolumn{2}{c}{ Pro activity } \\
\hline $\begin{array}{l}\text { \% of actual } \\
\text { requirements }\end{array}$ & phenological stages & 2014 & 2015 & 2014 & 2015 \\
\hline Control 100\% & during all stages & 1.06 & 0.98 & 0.035 & 0.043 \\
\hline \multirow{3}{*}{$120 \%$} & stage I (F-I.FS) & 0.92 & 0.86 & 0.023 & 0.029 \\
& stage II (I.FS - F.FS) & 0.86 & 0.87 & 0.030 & 0.033 \\
& stage III (F.FS- H) & 0.93 & 0.90 & 0.032 & 0.037 \\
& stage IV (H - D) & 0.88 & 0.84 & 0.030 & 0.041 \\
\hline & stage I (F-I.FS ) & 1.19 & 1.08 & 0.039 & 0.052 \\
& stage II (I.FS - F.FS) & 1.28 & 1.29 & 0.034 & 0.049 \\
& stage III (F.FS- H) & 1.77 & 1.78 & 0.040 & 0.045 \\
& stage IV (H - D) & 1.77 & 1.88 & 0.050 & 0.057 \\
\hline \multirow{3}{*}{$60 \%$} & stage I (F-I.FS ) & 1.85 & 1.81 & 0.058 & 0.072 \\
& stage II (I.FS - F.FS) & 1.26 & 1.21 & 0.054 & 0.055 \\
& stage III (F.FS- H) & 2.06 & 2.10 & 0.064 & 0.062 \\
& stage IV (H - D) & 1.86 & 1.99 & 0.054 & 0.063 \\
\hline
\end{tabular}

\section{Endogenous phytohormones}

Both the ABA and Salicylic acid (SA) contents of terminal buds was at its' highest magnitude when $60 \%$ of the actual water requirements were applied. This magnitude decreased by increasing the applied water quantities for the same phenological stage to reach the utmost with the $120 \%$ treatment. With respect to both the $\mathrm{GA}_{3}$ and the CKs contents an opposite trend was identified. Their magnitudes for the same phenological stage decreased by the decrease in the applied water quantities to reach their lowest limit with the application of the $60 \%$ of the actual irrigation requirements. The effect of applied water regime on the IAA content followed a third trend. Its' magnitude for the same stage increased by increasing the applied water from 60 to $80 \%$ of the actual water requirements. A further increase in this content was detected when increasing the applied water to $120 \%$ of the requirements for both stages III\&IV. Whereas, for stages I \&III a decrease in the IAA content was detected. (Table 9).

Table 9. Effect of water regime on some Phytohormones

\begin{tabular}{llllllr}
\hline \multirow{2}{*}{$\%$ of actual requirements } & \multicolumn{1}{c}{ phenological stages } & \multicolumn{4}{c}{ Phytohormones } \\
\cline { 3 - 7 } Control 100\% & during all stages & 0.0027 & 0.025 & 0.0043 & 0.034 & 3.27 \\
\hline \multirow{3}{*}{$120 \%$} & stage I (F-I.FS) & 0.0023 & 0.011 & 0.0080 & 0.037 & 3.99 \\
& stage II (I.FS - F.FS) & 0.0020 & 0.020 & 0.0060 & 0.036 & 3.88 \\
& stage III (F.FS- H) & 0.0025 & 0.021 & 0.0061 & 0.036 & 3.76 \\
& stage IV (H - D) & 0.0022 & 0.010 & 0.0073 & 0.038 & 3.41 \\
\cline { 2 - 7 } & stage I (F-I.FS ) & 0.0053 & 0.029 & 0.0006 & 0.025 & 3.25 \\
$80 \%$ & stage II (I.FS - F.FS) & 0.0046 & 0.026 & 0.0006 & 0.031 & 3.22 \\
& stage III (F.FS- H) & 0.0048 & 0.037 & 0.0008 & 0.019 & 3.24 \\
& stage IV (H - D) & 0.0051 & 0.026 & 0.0009 & 0.018 & 3.22 \\
\hline \multirow{3}{*}{$60 \%$} & stage I (F-I.FS ) & 0.0071 & 0.032 & 0.00018 & 0.02 & 2.89 \\
& stage II (I.FS - F.FS) & 0.0057 & 0.031 & 0.00030 & 0.01 & 2.95 \\
& stage III (F.FS- H) & 0.0074 & 0.039 & 0.00054 & 0.014 & 2.54 \\
& stage IV (H - D) & 0.0078 & 0.037 & 0.00050 & 0.014 & 2.12 \\
\hline
\end{tabular}

The attained results showed that vegetative growth parameters were statistically enhanced by increasing the applied water quantities during any of the considered stages. These results are in agreement with Marsal et al., 2000, 2002a). ) on pears, (Behboudian et al., 1998) on apples and Sebahattin et al. (2010) on 'Salak' apricot

Water stress was found to decrease the cytokinins_transfer_from root to shoots and increases the amount of leaf abscisic acid. These changes in hormone balance causes_decrease_in shoot growth and enlargement and leaf_expansion_Atkinson et al., 2000). Also our results declared clear increments in growth promoting hormones in parallel with increasing the applied water

Our findings are in agreement with those of (Naqvi 1995 and Itai 1999). 
These changes ultimately lead to alterations in cell division, extension, and differentiation at the cellular level, and consequently to a wide range of changes at the whole plant level (Gray et al., 2001; Kepinski and Leyser 2004).

Also, reduction in tree growth under water deficit condition could be attributed to a marked decrease photosynthetic rate and stomatal_conductance (Mpelasoka et al., 2001).In addition to the competition between the vegetative growth and the developing fruits on the limited carbohydrate that are produced

Decreasing the applied water quantities was accompanied by higher levels of proline. Similar trends were illustrated by El- Seginy, 2006 on Canino apricot, Mikhael and Mady, 2007 on Anna apple.

Several verifications were set for the afore mentioned findings as the inhibition of both proline dehydrogenase and proline oxidase enzymes exhibited under water stress (Verranjaneyulu and Kumari, 1989), also the crucial role of proline for osmatic adjustment (Watanabe, et al., 2000).

Decreasing the applied water quantities during any stage, significantly induced higher leaf carbohydrates content. Parrallel findings were attained by this results are findings by Al-Humaid and Mazrou(1998) and Agbemafle et al. (2015).

These results may be due that carbohydrates are the main organic solutes involved in plant osmotic adjustment which may lead to a decrease in leaf osmotic potential to maintain turgor and this is also an important adaptive mechanism in plants subjected to deficit irrigation (Hessine et al., 2009).

Similar findings on leaf phenol content changes as affected by irrigation regime was achieved by, Bolat et al. (2014) on M9 apple and MA quince rootstocks.

Polyphenol oxidase (PPO) and Peroxidase (Pro) activities were in an inverse proportion with the applied water quantities and these results agree with Shivashankar (1988) on palms and Aganchich et al. (2007).

Polyphenol oxidase (PPO) and peroxidase (Pro) activities are pivotal for the maintenance of membrane integrity under soil drying conditions. These conditions produce secondary oxidative stress that damages cellular membranes and macromolecules (Edreva, 2005). Peroxidase plays a role in modifications of cell wall properties causing reduced rates of cell wall expansion (Fry 1995), by it's playing a role in lignification (Quiroga et al., 2000).

Clear increments in both ABA and Salicylic acid content were induced with decreasing the applied water regime and vice versa.

In our opinion this response might be attributed to several reasons as that ABA up regulates the processes involved in cell turgor maintenance and synthesis of osmoprotectants and antioxidant enzymes conferring desiccation tolerance (Chaves et al., 2003) and synthesis of storage proteins and lipids (Sreenivasulu et al., 2010) and antitranspirant activity, notably stomatal closure and reduced leaf expansion (Wilkinson et al., 2012) and synthesis of LEA proteins, dehydrins, and other protective proteins (Sreenivasulu et al., 2012).

Salicylic acid plays a vital role in the regulation of plant growth and development, as well as responses to abiotic stresses (Hara et al., 2012). Salicylic acid is involved in plant response to abiotic stresses such as drought (Miura et al., 2013), SA along with $\mathrm{ABA}$ is involved in the regulation of drought resistance (Miura and Tada, 2014).

\section{Conclusion}

Increasing the applied water quantities at any of the four classified stages was accompanied by increasing the protein, GA3, IAA and the CKs contents and decreasing polyphenol oxidase (PPO), Peroxidase (Pro) activates. The response to the afore endogenous changes or maybe some of them in our opinion is clear enhancements in vegetative growth parameters. On the concontrary decreasing the applied water quantities was accompanied by higher leaf carbohydrates, phenols, polyphenol oxidase (PPO), Peroxidase (Pro) activates, ABA and Salicylic acid contents which might illustrate the induction of decreased vegetative growth

\section{References}

Aganchich B., Tahi H., Wahbi S., Elmodaffar C., Serraj R., 2007. Water relations, photosynthesis, growth and water use efficiency in tomato plants subjected to partial rootzone drying and regulated deficit irrigation. Plant Biosyst.; 141:252-264.

Agbemaf R. le1, J.D. Owusu-Sekyere, A. BartPlange, 2015. Effect of deficit irrigation and storage on the nutritional composition of tomato (Lycopersicon esculentum Mill. cv. Pectomech). Croatian Journal of Food Technology, Biotechnology and Nutrition, 10: 59-65.

Al-Humaid, A.I., Mazrou, M.M., 1998. Physiologican influences of different soil moisture levels on some Gladiolus gandavensis cultivars. II. Dry matter yield, water use efficiency and some chemical constituents. Menofiya. J. Agric. Res., 23: 169-179

Allen, R.G.; L.S.P. Creira; D. Raes and M. Smith, 1998. Crop evapotranspiration. Irrigation and Drainage Paper No. 56, FAO, Rome, Italy.

Angelopoulos, K. ; B. Dichio, C. Xiloyannis, 1996. Inhibition of photosynthesis in olivetrees (Olea europaea L.) during water stress and rewatering, J. Exp. Bot. 47:1093-1100.

Atkinson C. J., M. Policarpo, A. D. Webster, and G. Kingswell, 2000. "Drought tolerance of clonal Malus determined from measurements of 
stomatal conductance and leaf water potential," Tree Physiology, 20: 557-563.

Atkinson, C.J., A.D. Webster, S.P. Vaughan, L. Toylor and G. Kingswell, 2000. Interaction between root restriction, irrigation and rootstock treatments on Queen Cox apple trees: Effect of soil and plant water relation. J. Hort. Sci. Biotech., 75: 376-382.

Bates LS, Waldren RP, Teara ID., 1973. Rapid determination of free proline for water stress studies. Plant and Soil, 39: 205-207.

Behboudian, M. H., Lawes, G.. S. and Griffiths, K. M., 1994. The Influence of Water Deficit on Water Relations, Photosynthesis and Fruit Growth in Asian Pear (Pyrus serotina Rehd.). Sci. Hortic. 60: 89-99.

Ben C. ; A., B. Ben Rouina, S. Sensoy, M. Boukhris, F. Ben Abdallah, 2009. Changesin gas exchange, proline accumulation and antioxidative enzyme activities inthree olive cultivars under contrasting water availability regimes, Environ.Exp. Bot. 67:345-352.

Bergmeyer, H.U., 1974. Methods of Enzymatic Analysis. 4. New York: Academic Press. pp. 2066-72.

Bolat, I.; M. Dikilitas, S. Ercisli, A. Ikinci, and T. Tonkaz, 2014. The Effect of Water Stress on Some Morphological, Physiological, and Biochemical Characteristics and Bud Success on Apple and Quince Rootstocks. ScientificWorldJournal. Volume 2014, Article ID 769732, 8 pages

Boyer, J.S.; P.A. Armond, P.E. Sharp, 1987. Light stress and leaf water relations, in:D.J. Kyle, C.D. Osmond, C.J. Arntzen (Eds.), Photoinhibition, Topics in Photo-synthesis, 9: 111-122.

Chalmers, D. J., G.Burge, , P. H. Jerie, P. D. Mitchell, 1986. The Mechanism of Regulation of 'Bartlett' Pear Fruit and Vegetative Growth by Irrigation Withholding and Regulated Deficit Irrigation. J. Amer. Soc. Hort. Sci., 111(6): 904907 .

Chalmers, D. J., P. D. Mitchell , L. van Heek, 1981. Control of Peach Tree Growth and Productivity by Regulated Water Supply, Tree Density and Summer Pruning. J. Amer. Soc. Hort. Sci., 106: 307- 12 .

Chaves M.M., M.M. Oliveira, 2004. Mechanisms underlying plant resilience to water deficits: prospects for water-saving agriculture. J. Exp. Bot.;55:2365-2384.

Chaves, M.M. ; J.S. Pereira, J. Maroco, 2003. Understanding plant response to droughte from genes to the whole plant, Funct. Plant Biol. 30:126.

Cohen, A. and A. Goell, (]1988)]. Fruit Growth and Dry Matter Accumulation in Grapefruit during Periods of Water with Holding and after Reirrigation. Aust. J. Plant Physiol.15: 633-639.
Daniel, H.D and C.M. George, 1972. Peach seed dormancy in relation to indogenous inhibition and applied growth substances J. of American society of Horticulture Science, 97, 651-654.

Dichio, B.; C. Xiloyannis, A. Sofo, G. Montanaro, 2005. Osmotic regulation in leavesand roots of olive trees during a water deficit and rewatering, Tree Physiol. 26:179-185.

Duncan, D.B., 1955. Multiple range and multiple Ftests- Biomelerices, II: 1-42.

Edreva A., 2005. Generation and scavenging of reactive oxygen species in chloroplasts: a submolecular approach. Agriculture, Ecosystems and Environment 106(2):119-133.

El- Seginy, A.M., 2006. Response of Canino apricot trees to different irrigation and potassium treatments. Alex. Sci. Exchange J., 27: 64-75.

FAO, 1998. Irrigation and Drainage Paper No. 56 Crop Evapotranspiration (guidelines for computing crop water requirements). $300 p$

FAO, 2006. Review of global agricultural water use per country. Aquastat (FAO's Information System on Water and Agriculture. [On line]. Available in http:// www.fao.org/nr/water/aquastat/main/index.stm.

FERERES E., G..A., 1990. Deciduous fruit and nut trees. In: Irrigation of agricultural crops (Stewart B.A., Nielsen D.R., eds). American Society of Agronomy, Madison, WI, USA. pp. 987-1017.

Fry S., 1995. Polysaccharide-modifying enzymes in the plant cell wall. Annu. Rev. Plant Physiol. Plant Mol. Biol.;46:497-520.

García-Tejero I., J.A. Jiménez-Bocanegra, G. Martínez, R . Romero, V.H. Durán-Zuazo, J.L. Muriel-Fernández, 2010. Positive impact of regulated deficit irrigation on yield and fruit quality in a commercial citrus orchard. Agric Water Manage 97: 614-622.

Girona, J., M.Gelly, M.Mata , A.Arbones, J.Rufat, J. Marsal, 2005. Peach Tree Response to Single and Combined Deficit Irrigation Regimes in Deep Soils. Agric. Water Manage., 72(2): 97-108.

Grace, S.C., 2005. Phenolics as antioxidants, in: N. Smirnoff (Ed.), Antioxidants and Reactive Oxygen Species in Plants, Blackwell, UK, , pp. 141-168.

Gray W.M., S. Kepinski, D. Rouse, O. Leyser, M. Estelle, 2001. Auxin regulates SCFTIR1dependet degradation of AUX/IAA proteins. Nature 414:271-276.

Hara, M.; J. Furukawa, A. Sato, T. Mizoguchi, K. Miura, 2012. Abiotic stress and role of salicylic acid in plants, in: A. Parvaiz, M.N.V. Prasad (Eds.), Abiotic Stress Responses in Plants, Springer, New York, pp. 235-251.

Hessine, K., J.P. Martínez, M. Gandour , A. Albouchi, A. Soltani, C.Abdelly, 2009. Effect of water stress on growth, osmotic adjustment, cell wall elasticity and water-use efficiency in 
Spartina alterniflora. Environ. Exp. Bot. 67, 312319.

Ingram, J. ; D. Bartels, 1996. The molecular basis of dehydration tolerance in plants,Annu. Rev. Plant Physiol. Plant Mol. Biol. 47 :377-403.

Itai, C., 1999. Role of phytohormones in plant responses to stresses. - In: Lerner, H.R. (ed.): Plant Responses to Environmental Stresss. From Phytohormones to Genome Reorganization. Pp. 287-301. Marcel Dekker, New York - Basel.

Jackson, M. L., 1973. Soil Chemical Analysis, Prentice Hall of India (P) Ltd., New Delhi.

Kar M, D. Mishra, 1976. Catalase, peroxidase and polyphenoloxidase activities during rice leaf senescence. Plant Physiol 57: 315-319

Karmeli and Keller, 1975. Irrgation design. MFg. Co., Glendora, Calif., p. 193.

Kepinski S. and O. Leyser, 2004. Auxin induced SCFTIR1-AUX/IAA interaction involves stable modification of the SCFTR1 complex. Proc. Natl. Acad. Sci. USA 101: 12381-12386.

Knegt, E. and Brunima, J.,1973. Rapid sensitive and accurate determination of indole-3-acetic acid. Phytochem. 12: 573-576.

Kong X.F.1., Zhu X.H., Pei Y.L., Jackson D.M., Holick M.F. (1999). Molecular cloning, characterization, and promoter analysis of the human 25-hydroxyvitamin D3-1alphahydroxylase gene. Proc Natl Acad Sci U S A. 8;96(12):6988-93.

Kuwabara T., Katoh Y., 1999. Involvement of the binuclear copper site in the proteolytic activity of polyphenol oxidase. Plant Cell Physiol.;40:10291035.

Le, SH; Huguet, J.G.; Schoch, P.G. and Orlando, P., 1989. Responses of peach tree growth and cropping to soil water deficit at various phonological states of fruit development. J. Hortic., Sci., 64: 541-552.

Lee F.J., Lin L.W., Smith J.A., 1989. N alpha acetylation is required for normal growth and mating of Saccharomyces cerevisiae. J Bacteriol 171(11):5795-802

Li, S. H., Huguet, J. G., Schoch, P. G. and Orlando, P., 1989. Responese of Peach Tree Growth and Cropping to Soil Water Deficit at Various Physiological Stages of Fruit Development. J. Hort. Sci., 64(5): 541-542.

Lowry, O.H., N.J. Rosebrough, A.L. Farr, and R.J. Randall, 1951. Protein Measurement with the Folin Phenol Reagent. J. Biol. Chem. 193:265-275

Marsal, j., M. Mata, A. Arbones, J. Rufat, and J. Cirona, 2002a. Water stress limits for vegetative and reproductive growth of 'Bartlett' pears. Acta Hart. 596:659-664.

Marsal, J., Rapoport, H. F., Manrique, T. and Girona, J., 2000. Pear Fruit Growth under Regulated Deficit Irrigation in Container-grown Trees. Sci. Hort., 85: 243- 259.
Mikhael, G.B. and A.A. Mady, 2007. Effect of some drip irrigation and mulching treatments on: II. Yield, fruit quality and water use efficiency of Anna apple trees grown in new reclaimed soils. Minufiya. J. Agric. Res., 32: 1175-1191.

Mitchell P.D., Jerie P.H., Chalmers D.J., 1984. Effects of regulated water deficits on pear tree growth, flowering, fruit growth and yield. J Amer Soc Hort Sci 109, 604-606.

Mitchell, P.D., Chalmers, D.J., Jerie, P.H. \& Burge, G., 1986. The use of initial withholding of irrigation and tree spacing to enhance the effect of regulated deficit irrigation on pear trees. Journal of the American Society of Horticultural Science 111: 858-861.

Miura, K. ; H. Okamoto, E. Okuma, H. Shiba, H. Kamada, P.M. Hasegawa, Y. Murata, SIZ1, 2013. deficiency causes reduced stomatal aperture and enhanced drought tolerance via controlling salicylic acid-induced accumulation of reactive oxygen species in Arabidopsis, Plant J. 49, 79-90.

Miura, K. ; Y. Tada, 2014. Regulation of water, salinity, and cold stress responses by salicylic acid, Front. Plant Sci. 5, 4, http://dx.doi.org/10.3389/fpls.2014.00004.

Mpelasoka, B.S., M.H. Behboudian and T.M. Mills, 2001. Water relation, photosynthesis, growth, yield and fruit size of Braeburn apple: Responses to deficit irrigation and to crop load. J. Hort. Sci. Biotech., 70: 150-156.

Mukherjee SP, Choudhuri M.A., 1983. Implications of water stress induced changes in the levels of endogenous ascorbic acid and $\mathrm{H} 2 \mathrm{O} 2$ in Vigna seedlings. Plant Physiol. 58:166-170.

Naqvi, S.S.M., 1995. Plant/crop hormones under stressful conditions. In: Pessarakli, M. (ed.): Handbook of Plant and Crop Physiology. Pp. 645-660. Marcel Dekker, New York - Basel Hong Kong.

PÉREZ-PASTOR A., DOMINGO R., TORRECILLAS A., RUIZ-SÁNCHEZ M.C., (2009). Response of apricot trees to deficit irrigation strategies. Irrig Sci 27, 231-242.

Pretorius J. J. B. and S. J. E. Wand, 2003. "Lateseason stomatal sensitivity to microclimate is influenced by sink strength and soil moisture stress in "Braestar" apple trees in South Africa," Scientia Horticulturae, vol. 98, no. 2, pp. 157171.

Quiroga M., Guerrero C., Botella M.A., Barcelo A., Amaya I., Medina M.I., Alonso F.J., de Forchetti S.M., Tigier H., Valpuesta V. A., 2000. tomato peroxidase involved in the synthesis of lignin and suberin. Plant Physiol.;122:1119-1127.

Rejsková, A.; L. Patková, E. Stodulková, H. Lipavská, 2007. The effect of abioticstresses on carbohydrate status of olive shoots ( Olea 
europaea L.) underin vitro conditions, J. Plant Physiol. 164 :174-184.

Rice-Evans C.A., Miller N.J., Paganga G., 1997. Antioxidant properties of phenolic compounds. Trends Plant Sci.;2:152-159.

Sebahattin Kaya, Salih Evren, Erdal Dasci, M. Cemal Adiguzel and Hasbi Yilmaz, 2010. Effects of different irrigation regimes on vegetative growth, fruit yield and quality of dripirrigated apricot trees. African Journal of Biotechnology Vol. 9(36), pp. 5902-5907.

Shivashankar S., 1988. Polyphenol oxydase isozymes in coconut genotypes under water stress. Plant Physiol. Biochem.;15:87-91.

Smith, N., 1991. "CROPWAT" model for Eto calculation using Penman Monteith Method. FAO, Rome, Italy.

Snedecor, G. W. and Cochran, W. G., 1980. Statistical Methods, 6th ed., Iowa State Univ. Press, Iowa, USA.

Soad, M.M. I., 2005. Response of vegetative growth and chemical composition of jojoba seedlings to some agricultural treatments. Ph.D. Thesis, Fac. Of Agric. Minia Univ. Egypt.

Sofo A., Dichio B., Xiloyannis C., Masia A., 2005. Antioxidant defence in olive trees during drought stress: changes in activity of some antioxidant enzymes. Funct. Plant Biol.;32:45-53.

Sreenivasulu, N.; V. Radchuk, A. Alawady, L. Borisjuk, D. Weier, N. Staroske, J. Fuchs, O. Miersch, M. Strickert, B. Usadel, U. Wobus, B. Grimm, H. Weber, W. Weschke, 2010. De- regulation of abscisic acid contents causes abnormal endosperm development in the barley mutant seg8, Plant J. 64, 589-603.

Sreenivasulu, N.; V.T. Harshavardhan, G. Govind, C. Seiler, A. Kohli, 2012. Contrapuntal role of ABA: does it mediate stress tolerance or plant growth retardation under long-term drought stress? Gene 506, 265-273.

Stefanelli, D., Goodwin, I., Jones, R., 2010. Minimal nitrogen and water use in horticulture Effects on quality and content of selected nutrients. Food Research: International, Vol. 43, No. 7, (Aug), pp. 1833-1843

Umbreit, W. W., Burris, R. G. \& Stauffer, J. H., 1964. in Manometric Techniques, p. 116, Burgess, Minneapolis Underwood, A. H. \& Newsholme, E. A. (1967) Biochem. J. 104, 300305

Verranjaneyulu, K. and B.D.R. Kumari, 1989. Proline metabolism during water stress in mulberry. J. Exp. Bot., 40: 581-583.

Watanabe, S., K. Kojima. Y. Ide and Satohiko Sasaki, 2000. Effect of saline and osmotic stress on proline and sugar accumulation in Populus euphratica in vitro. Plant Cell Tissue and Organ Culture, 63: 199-206.

Wilkinson, S.; G.R. Kudoyarova, D.S. Veselov, T.N. Arkhipova, W.J. Davies, 2012. Plant hormone interactions: innovative targets for crop breeding and management, J. Exp. Bot. 63: 34993509 . 
تغير المحتوى الداخلى لاشجار الكمثرى الليكونت تحت المستويات المائية المختلفة وتاثيره على النمو الخضرى

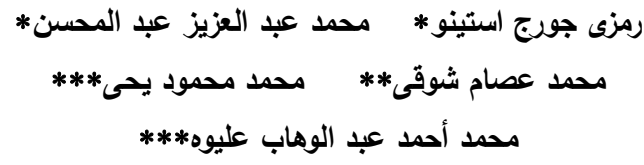

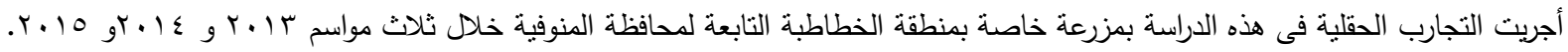

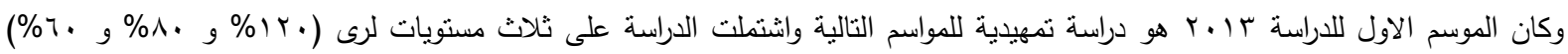
بالاضافة الى الاحتياج المائى · . 1\% خلال اربع مراحل فينولوجية مختلفة وهى المرحلة الاولى وهى من بداية التزهير الى العقد النهائى والمرحلة

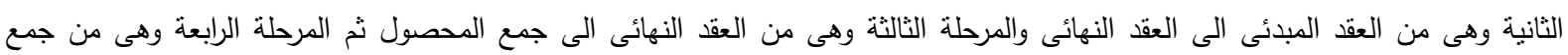
المحصول الى بداية تساقط الاوراق وكانت الاثجار تحت المستوى المائى لتجربة ثم باقى المراحل الاخرى تحت المستوى المائى الامثل ( ... (1\%) بالاضافة الى اشجار المقارنة (. (. 1\% في الاربع مراحل). كانت القياسات المؤخوذة وهى: النمو الخضرى ومحتوى الهرمونات الداخلية والبرولين والفينولات والبروتين والكربوهيدرات ونشاط الانزيمى لانزيم البولى فنيل اوكسيديز والبروكسيداز .

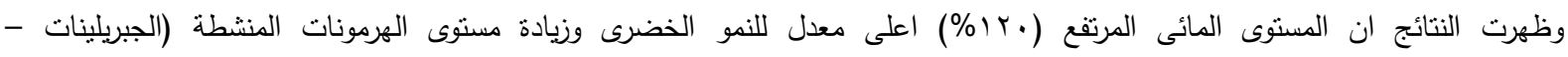
والسيتوكينينات - والاوكسينات) و محتوى الاوراق من البروتين وتقليل محتوى من البرولين والكربوهيدرات والفينولات والنشاط الانزيمى بينما كان المحتوى المائى المنخفض (•ب\%) ذو تاثير سلبى على النمو الخضرى وزيادة معدل الهرمونات المثبطة (الابسيسيك اسيد) على الهرمونات المنشطة وارتفاع معدل البرولين والكربوهيدرات والفينولات وانزيمى البولى فنيل اوكسيديز والبروكسيداز .

الكلمات الدالة: الكمثرى الليكونت - النمو الخضرى- النشاط الانزيمى - البولى فنيل اوكسيديز - البروكسيداز - البرولين - الفينولات - البروتين - الجبريلينات - والسيتوكينينات - والاوكسينات 